\title{
STUDENT EXPERIENCE OF PERCEIVED CONNECTEDNESS IN ONLINE DESIGN EDUCATION
}

\author{
Christy Vivek GOGU and Jyoti KUMAR \\ Indian Institute of Technology Delhi
}

\begin{abstract}
Online courses have been on the rise in the last few decades and recently with the pandemic across the world, many traditional design schools have transitioned to the virtual realm to continue learning seamlessly. This study has focussed on understanding the perspective of students from various design schools in India about their experience with online courses and their perceived social connectedness. This paper reports findings from a combination of quantitative and qualitative study, wherein sixty four students from five design schools across India responded anonymously to the online survey. This study assesses the level of social connectedness that students perceived with their instructors and fellow students in online classes. This paper also discusses some of the reasons for this perception, as articulated by the participants and reports a significant correlation found between felt connectedness and various factors in online learning. It was observed that while the given student populace seemed adept in online communication and exchange of information, their feedback on online classes revealed deeper insights into the aspects that affect their overall experience of design education. In addition, we submit some of the features or elements of traditional face-to-face (F2F) classrooms that students miss the most in the current online setting.
\end{abstract}

\section{Keywords: Online design learning, connectedness, design education, virtual classrooms}

\section{INTRODUCTION}

In the last few decades there has been a rise in online education around the world. Increased computer literacy and internet connectivity, growth in distance learning opportunities, many reasons contribute to this increase in popularity of online courses. Countries are increasingly investing in online and multimedia based courses [1]. Whereas design education is still not readily available online [2].

Social interactions are instrumental for human physical and psychological well-being. Social connectedness, which has been characterized as one of the main motivating principles behind social behaviour, is usually considered as a predictor of a successful life and it has been associated with many social and health-related benefits [3], [4]. Several researchers have recently provided empirically based guidelines for creating and maintaining social connectedness online that include strategies designed to facilitate status assessments, norm development, and role differentiation in computer-mediated communication channels that often lack the subtle social cues people use in face-to-face(F2F) interactions [5], [6]. Laffey, et al [7] claim education and various learning interactions, whether traditional F2F or virtual, to be social practices. The extent to which students in online learning environments perceive themselves as being socially connected to their peers appears to be a key factor in predicting the success of online courses [8]. While fruitful social interactions happen relatively effortlessly in F2F learning settings, creating and maintaining these social connections in online learning environments requires active support and, often, instructor facilitation [9].

In design education, some research has been done to inquire into the effectiveness and success of these courses but not much has been done to fully understand the impact on learning in online platforms [10]. With Studio-based learning being at its core, design courses usually have small class sizes. They typically use project work and collaborative creative problem solving with many possible solutions [11]. Research shows that online collaboration in design can be successfully done only if student participation is high and instructor feedback is instantaneous [12]. The characteristics of studio-based teaching in design, have been identified as supporting interaction, active learning, as well as social engagement [13], thereby involving high social connectedness amongst students and instructors. 
Slagter van Tryon \& Bishop [14] developed the Social Perceptions in Learning Contexts Instrument (SPLCI), a research tool for measuring students' perception of the social connectedness in online courses. Not many technically validated instruments are available for instructors to collect data necessary to evaluate the success or failure of these pedagogical methods.

This study aims at evaluating student experience of perceived connectedness in online design courses to understand the impact, if any, of social connectedness on course understanding and motivations.

\section{METHODS}

An inductive research approach was adopted to investigate and make observations to arrive at conclusions [15]. Data was collected from graduate and post graduate level design students doing a combination of theory and practical courses in Product Design, Transportation Design and UX design from UPES School of Design, United World Institute of Design, Pearl Academy Delhi, ISDI Mumbai and Department of Design IITD. An online survey with closed and open-ended questions to study student behaviour and responses with respect to online design courses was considered to be the most suitable method to gather students' feedback for various reasons. Online surveys gave the advantage of reaching a greater number of participants in a short time, without any geographical constraints. They were used to collect both quantitative and qualitative data at the same time. It gave students the flexibility to participate as per their convenience of place and time. They also support the anonymity of respondents, allowing greater honesty and higher participation when well-designed, fast and easy to complete [16].

A 5-point Likert scale was employed, and students picked from a range of responses, Always(5), Often(4), Sometimes(3), Occasionally(2), and Never(1) [17], to help answer the 'what?' questions while the open ended questions allowed students to give in-depth information, answering the 'why?' questions about their experiences [18]. Sixty four students from 5 design schools across India responded to the survey. These students had spent a majority of their course time in traditional F2F classes and had experienced the online classes only for 2-3 months prior to the survey.

The quantitative data obtained using the online surveys was analysed by using the existing tools from the survey platform, Google forms. This data was also analysed to find any possible correlation between the variables and felt connectedness. The qualitative data obtained from the open-ended questions were coded and categorised into themes and subthemes. Similar codes were combined into subcategories and their frequency of occurrence was counted to evaluate importance. The findings, analysis and discussion are presented in the next section.

\section{RESULTS AND ANALYSIS}

The results and analysis done during the study have been shown in the following tables.

\subsection{Online Class Hours and Platforms used}

Tables 1 and 2 show the no. of hours spent and the online platforms used by them for design courses.

Table 1. Online design class hours

\begin{tabular}{l|c|c|c|c|c}
\hline Online class hrs per week & $<5$ & $6-10$ & $11-14$ & $15-19$ & $>20$ \\
\hline No. of students & 39 & 9 & 6 & 2 & 8 \\
\hline
\end{tabular}

Table 2. Online platforms used for classes

\begin{tabular}{l|c|c|c|c|c}
\hline Online class platform & Zoom & BB Collaborate & Google Meet & MS Teams & Others \\
\hline No. of students & 58 & 11 & 10 & 4 & 5 \\
\hline
\end{tabular}

It may be noted that some students used more than one platform for online classes. Therefore, a majority of students spent not more than an hour each day in online classes and the most popular(or preferred) platform was Zoom. Students also used social media or other online platforms like WhatsApp, Miro and Mural to connect outside of online classes to collaborate and work on projects.

\subsection{Virtual Behaviour and Class Participation}

The students indicated how often they displayed certain behaviour online as shown in table 3 .

\section{Table 3. Virtual behaviour and experience in online classes}




\begin{tabular}{l|c|c|c|c|c|c|c}
\hline $\begin{array}{l}\text { Virtual Behaviour and } \\
\text { experience }\end{array}$ & $\begin{array}{c}\text { Always } \\
(\mathbf{5})\end{array}$ & $\begin{array}{c}\text { Often } \\
(\mathbf{4})\end{array}$ & $\begin{array}{c}\text { Sometimes } \\
\mathbf{( 3 )}\end{array}$ & $\begin{array}{c}\text { Occasionally } \\
\mathbf{( 2 )}\end{array}$ & $\begin{array}{c}\text { Never } \\
(\mathbf{1})\end{array}$ & Mean & Var. \\
\hline Video ON & 2 & 6 & 18 & 25 & 13 & 2.35 & 1.03 \\
\hline Verbal Interaction & 8 & 17 & 15 & 18 & 5 & 3.05 & 1.44 \\
\hline Course Interest & 13 & 31 & 11 & 5 & 3 & 3.70 & 1.10 \\
\hline Course Understanding & 7 & 28 & 22 & 4 & 2 & 3.52 & 0.83 \\
\hline Connectedness with Instructor & 6 & 12 & 21 & 14 & 10 & 2.81 & 1.46 \\
\hline Connectedness with peers & 2 & 5 & 20 & 22 & 14 & 2.33 & 1.05 \\
\hline
\end{tabular}

Here, would be an appropriate place to note that the respondents were not given a clear definition of 'social connectedness' or 'connectedness', instead were required to use their own perceptions and understanding of 'connectedness'. The terms used in table 3 are described further to better understand the questions asked in the survey. 'Video ON' corresponds to how often the students kept their video camera turned ON during classes. 'Verbal interaction in class' corresponds to how often the students interacted with the instructor or co-students during the classes. 'Course Interest' corresponds to how often the students were interested in the course they were attending, while 'Course Understanding' corresponds to how often the students understood everything that was being taught in online classes. 'Connectedness with Instructor/peers' indicates how often the students felt connected with the instructor/peers during online classes.

\subsection{Correlation between Variables and Connectedness}

Pearson's correlation was applied to see the relationship between variables (frequency of keeping video $\mathrm{ON}$, verbal interaction in class, interest in course and course understanding) and the felt connectedness with instructor and/or co-students. Significant positive correlation was found as shown in the table 4 .

Table 4. Correlation between Variables and Connectedness

\begin{tabular}{lcc}
\hline Correlation with Connectedness (r.) & With Instructor & With Co-students \\
\hline Video ON & - & .267 \\
\hline Verbal Interaction & .291 & .207 \\
\hline Course Interest & .419 & .255 \\
\hline Course Understanding & .249 & - \\
\hline A
\end{tabular}

A significant positive correlation is seen especially between Connectedness with the Instructor and Course Interest. This indicates that the students were more interested in the course when they felt higher levels of connectedness with the instructor. Further, when students kept their videos ON more often, they felt more connected with their co-students. Similarly, higher verbal interactions in class led to higher felt connectedness with the instructor and/or co-students. Significant correlation was also seen between the level of connectedness felt with the instructor and the understanding of the course taught. Further, the qualitative data obtained from the responses to the open ended questions in the survey were tabulated based on the frequency of common themes that emerged from coding them. These tables help us gain some understanding of the 'why' behind the 'what', the reasons that made the students feel or not feel a sense of connectedness during the online classes.

\subsection{Problems Faced during Online Classes}

It was found that the most common technical problems faced by the students during online classes were power/internet connectivity or interruptions and having to stare at the screen for a long duration of time. While some faced audio issues, a few also had to face distractions at home.

\subsection{Reasons for Perceived Connectedness}

Table 5. Reasons for perceived Connectedness in Online Classes

\begin{tabular}{|c|c|c|}
\hline Reasons (no. of mentions) & $\begin{array}{c}\text { No. of } \\
\text { mentions }\end{array}$ & Sample responses \\
\hline $\begin{array}{l}\text { Interactions: } \\
\text { Discussions/teamwork (19) } \\
\text { Chat options (13) }\end{array}$ & 32 & $\begin{array}{l}\text { 'A lot of students live in different cities } \\
\text { and family environments which impacts } \\
\text { thoughts and ideas, it was interesting to see }\end{array}$ \\
\hline
\end{tabular}


and hear the variety of ideas that came

from other students while at home.'

\begin{tabular}{|c|c|c|}
\hline $\begin{array}{l}\text { Visual presence: } \\
\text { Being able to see others; Video on (8) } \\
\text { Knowing my classmates are there (4) }\end{array}$ & 12 & $\begin{array}{l}\text { 'If their videos were on and verbal } \\
\text { communication ensued', 'The feeling of } \\
\text { nostalgia that we mutually shared' }\end{array}$ \\
\hline $\begin{array}{l}\text { Instructor input: } \\
\text { Voice/video/feedback(5), Course content(2) }\end{array}$ & 7 & $\begin{array}{l}\text { 'Interaction, familiar voices' } \\
\text { 'Getting timely feedback from mentor' }\end{array}$ \\
\hline None/Not sure & 13 & $\begin{array}{l}\text { 'It's really hard. Required lots of effort. } \\
\text { Nothing ever really helped' }\end{array}$ \\
\hline
\end{tabular}

The most common factor that helped students feel a sense of connectedness in online classes was having interactions with the instructors or students and doing collaborative work as part of class. The chat option in some of the platforms also aided in connectedness. More than a sixth of the respondents felt there was nothing that helped them feel connected in online classes.

\subsection{Reasons for lack of Perceived Connectedness}

Table 6. Reasons for lack of perceived Connectedness

\begin{tabular}{|c|c|c|}
\hline Reasons (no. of mentions) & $\begin{array}{c}\text { No. of } \\
\text { mentions }\end{array}$ & Sample responses \\
\hline $\begin{array}{l}\text { Physical/Visual absence } \\
\text { Can't see others/video OFF (7) } \\
\text { Not there physically (15) } \\
\text { Class environment missing (7) } \\
\end{array}$ & 29 & $\begin{array}{l}\text { 'You can't see or share eye contact or talk to } \\
\text { ppl... It's annoying', 'Workspace at home not fit } \\
\text { for design related work' }\end{array}$ \\
\hline $\begin{array}{l}\text { Lack of Interaction } \\
\text { No discussions (20) } \\
\text { Session too long (4) }\end{array}$ & 24 & $\begin{array}{l}\text { 'When the session went on for a long duration } \\
\text { and got monotonous', 'Some ideas are better } \\
\text { communicated through in person interactions and } \\
\text { ideation sketches are more difficult.' }\end{array}$ \\
\hline $\begin{array}{l}\text { Technical issues } \\
\text { Internet connection (12), Audio issues (7) }\end{array}$ & 19 & $\begin{array}{l}\text { 'Poor connection...', 'The confusion when } \\
\text { everyone talked at the same time' }\end{array}$ \\
\hline \multicolumn{3}{|c|}{$\begin{array}{l}\text { In attempting to find the reasons for the respondents' lack of felt connectedness in online classes, it was } \\
\text { found that almost half of them felt that physical and/or visual absence was a key reason followed by the } \\
\text { lack of interaction of students in the classroom or college campus. Attending classes from home also } \\
\text { added domestic distractions and made it difficult to be motivated and focused enough to work well. } \\
\text { Students also missed out on peer-learning and building on each other's ideas. }\end{array}$} \\
\hline
\end{tabular}

\subsection{Advantages of Online Classes}

The main advantage of the online courses, according to the study, was the convenience and flexibility it afforded the students to connect from the comfort of their homes or anywhere else. Ease of access to online resources and features like breakout groups and recording options were found beneficial, especially for theoretical courses. Students often used social media or online platforms like WhatsApp, Miro and Mural to connect outside of class time to connect, collaborate and work on group projects.

\subsection{Elements Missing in Online Classes}

In attempting to understand aspects of F2F classes the design students missed the most during online classes, the students responded descriptively, as summarised in Table 7, with a few sample responses.

Table 7. Elements missing in online classes

\begin{tabular}{|c|c|c|}
\hline Elements (no. of mentions) & $\begin{array}{c}\text { No. of } \\
\text { mentions }\end{array}$ & Sample responses \\
\hline $\begin{array}{l}\text { Interactions } \\
\text { Conversations/sharing ideas(13) } \\
\text { Debates/discussions(17) } \\
\text { Critique/feedback/clarification(10) } \\
\text { Accountability(1) } \\
\text { More focus(7) } \\
\text { Easier/faster learning(3) } \\
\end{array}$ & 51 & $\begin{array}{l}\text { 'The instant feedback while doing a work, project } \\
\text { or assignment to correct the mistakes and easily } \\
\text { move on', 'A very small but crucial element } \\
\text { missing for me was the little discussions we would } \\
\text { have with the other students about the same topic } \\
\text { while it was being taught } \Theta \text {. It added to the } \\
\text { understanding of the subject matter.' }\end{array}$ \\
\hline
\end{tabular}




\begin{tabular}{lcl}
\hline $\begin{array}{l}\text { Physical Presence } \\
\text { Being with/seeing each other(14) } \\
\text { Body language/expression(4), } \\
\text { Movement(3) }\end{array}$ & 28 & $\begin{array}{l}\text { 'Meeting friends, having fun in class, proper } \\
\text { discussions, looking at faces' }\end{array}$ \\
\hline $\begin{array}{l}\text { Ambience } \\
\text { Classroom/studio(8) }\end{array}$ & & $\begin{array}{l}\text { 'The atmosphere is different. It is after all a place } \\
\text { College/school(1) }\end{array}$ \\
$\begin{array}{l}\text { Learning/work environment(10) } \\
\text { nome or from other places doesn't have the same } \\
\text { effect', 'The workspace and people which made } \\
\text { the aura of a good working environment' }\end{array}$ \\
$\begin{array}{l}\text { Fun Aspect } \\
\begin{array}{l}\text { Laughter/fun activities(5) } \\
\text { Energy(3), Attachment(1) }\end{array}\end{array}$ & 9 & $\begin{array}{l}\text { 'The energy of the class sessions, with a lot of } \\
\text { back and forth interaction', 'Human interaction } \\
\text { that is organic and the laughter that came with } \\
\text { studying' }\end{array}$ \\
\hline Everything & 9 & 'Every single moment' \\
\hline
\end{tabular}

Affirming their previous responses, almost 80 percent of the respondents said they missed the animated discussions and organic interactions the most in the online setting. They explained how these discussions helped them get a better grasp of topics being taught in class or clear any doubts they have with their instructors. These interactions also helped them learn from their peers.

\section{DISCUSSIONS}

The results and analysis highlight the importance of being able to see each other and interact with people in physical space. While the internet is a great space to meet and connect with people, it has its own limitations due to the visual gap that can be closed only by physical presence and interaction, especially in online design education. And yet, we see many design instructors and students successfully exchanging knowledge and ideas to deliver and receive design education. While felt social connectedness of design school instructors and its effect on pedagogy has been reported earlier [19], in this study we found insights on how the students were responding to online design education and taking initiative to bridge the digital divide. Even though there is(and most likely, always will be) a clear preference for in person or F2F learning experience, we saw that students found ways to stay connected outside of online classes and discover and adapt to new platforms to collaborate for team projects by finding avenues to replicate in-person interactions and exchange of ideas. Design instructors therefore need to constantly encourage visibility and verbal interaction in online settings. They can further incorporate collaborative tools as add-ons to the online platforms they are currently using to encourage in-class participation and interaction, thereby heightening the learning experience for both the students and themselves.

\section{CONCLUSIONS}

This paper has reported that design students preferred traditional F2F learning environments rather than the online option due to the more holistic learning that happens due to focused learning and higher interest generated just by the experience of creative and curious minds learning and interacting together. It points out that the primary drawback of online classes was its lack of perceived social connectedness, immediate critique during ideation and organic group interactions. Whereas the primary advantage of an online learning mode was found to be the flexibility it grants in terms of location and time.

Considering the feedback from the survey participants, it can be concluded that:

1. Significant correlation was found between students' connectedness with instructor and the interest in a course, verbal interaction in class and understanding of the course. Correlation was also found between connectedness with co-students, visible faces and verbal interaction in class.

2. Perceived connectedness with the instructor and peers in virtual classrooms depends greatly on being able to see and interact with each other.

3. Current online platforms are not the easiest or most intuitive when it comes to receiving feedback or clarifying doubts.

4. Online classes reduce the possibility of collaborative work and group projects online, which is otherwise an integral part in traditional F2F classrooms. 
5. Lack of proper Internet and power connectivity are practical problems still faced by many students in many parts of developing India. Also, studio/workshop facilities and classroom environment is missing in online setups.

Most of these students had experienced online classes for only 3 months. Therefore, further research needs to be carried out over a longer duration to understand and compare the deeper impact of the social connectedness on design learning. Technology focused research would help identify features that can help make the online learning experience a more rewarding one.

\section{REFERENCES}

[1] Arya U. (2017). The Rise of MOOCs (Massive Open Online Courses) and Other Similar Online Courses Variants -Analysis of Textual Incidences in Cyberspace. Journal of Content, Community \& Communication Vol. 6 Year 3, June - 2017 [ISSN: 2395-7514 (Print)].

[2] Kumar P., Kumar A., Palvia S., and Verma S. (2019). Online business edu research: Sys. analysis and a conceptual model. The Intl Journal of Mgmt Edu, 17, 26-35.

[3] Riedl C., Köbler F., Goswami S., and Krcmar H. (2013). Tweeting to feel connected: A model for social connectedness in online social networks. International Journal of Human-Computer Interaction, 29, 670-687.

[4] Smith E. and Mackie D. Social psychology (2nd ed.), Psychology Press, New York, NY (2000).

[5] Slagter van Tryon P. J. E-mmediacy strategies for online learning: An instructor's guide and instrument for the design and evaluation of social connectedness in web-based courses. 2007. Lehigh University.

[6] Slagter van Tryon P. J. and Bishop M. J. Theoretical Foundations for Enhancing Social Connectedness in Online Learning Environments. November 2009. Distance Education 30(3):291-315. DOI: 10.1080/01587910903236312.

[7] Laffey J., Lin G. Y., and Lin Y. (2006). Assessing social ability in online learning environments. Journal of Interactive Learning Research, 17(2), 163 - 177.

[8] Kreijns K., Kirschner P. A., Jochems W., and van Buuren H. (2004). Determining sociability, social space, and social presence in (a)synchronous collaborative groups. Cyber Psychology \& Behaviour, 7, 155-172. doi:10.1089/109493104323024429.

[9] Reisetter M. and Boris G. (2004). Student perceptions of effective elements in online learning. Quarterly Review of Distance Education, 5, 277-291. Retrieved from http://www. aect.org/intranet/publications/qrde/subguides.html.

[10] Turner R. E., Rieger M., and Barrick R. K. Student Evaluation Scores for Courses Delivered by Interactive Videoconferencing NACTA Journal, Vol. 55, No. 1 (March 2011), pp. 16-20.

[11] Blair B. (2006). "At the end of a huge crit in the summer, it was "crap" - I'd worked really hard but all she said was "fine" and I was gutted.' Art, Design \& Communication in Higher Education, 5(2), 83-95. doi:10.1386/adch.5.2.83_1.

[12] Bender D. M. and Vredevoogd J. D. (2006). Using Online Education Technologies to Support Studio Instruction. Educational Technology \& Society, 9 (4), 114-122.5.

[13] Crowther P. (2013). Understanding the signature pedagogy of the design studio and the opportunities for its tech. enhancement. Journal of Learning Design, 6(3), 18-28.

[14] Slagter van Tryon P. J. and Bishop M. J. (2012) Evaluating social connectedness online: the design and development of the Social Perceptions in Learning Contexts Instrument, Distance Education, 33:3, 347-364, DOI: 10.1080/01587919.2012.723168.

[15] Morse J. M. and Niehaus L. (2009) Mixed Method Design: Principles and Procedures. Walnut Creek, CA: Left Coast.

[16] Gray C. and Malins J. (2004) Visualizing Research: A Guide to the Research Process in Art and Design. New York, USA: Burlington Ashgate.

[17] Robinson J. P., Shaver P. R., and Wrightsman L. S. (Eds.). (1991). Measures of social psychological attitudes, Vol. 1.Measures of personality and social psychological attitudes. Academic Press.

[18] Fribourg O. and Rosenvinge J. H. 2013. A comparison of open-ended and closed questions in the prediction of mental health. Quality and Quantity, 47 (3):1397-1411.

[19] Gogu C. V. and Kumar J. (2021) Social Connectedness in Online versus Face to Face Design Education: A comparative study in India. In Design for Tomorrow-Volume 2, Smart Innovation, Systems and Technologies 222, https://doi.org/10.1007/978-981-16-0119-4_33. 